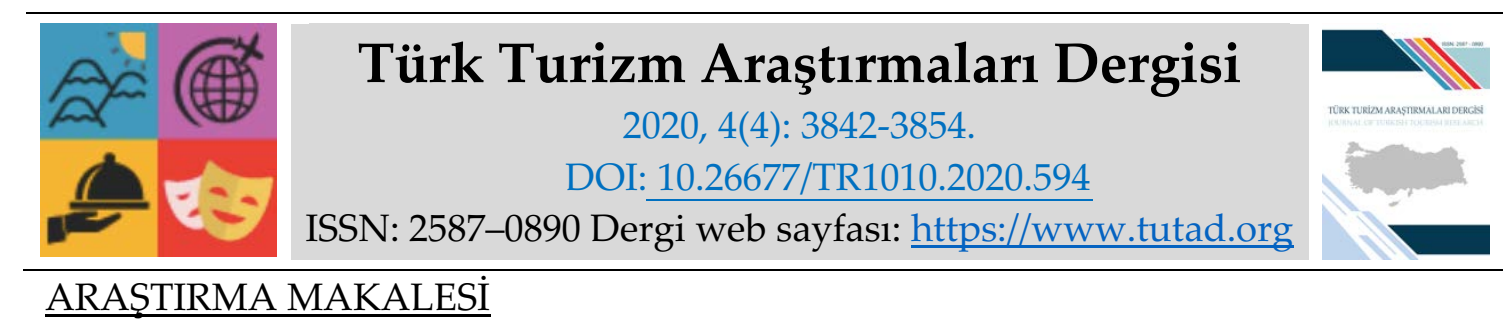

\title{
İş Yerinde Cinsel Taciz ile İş Doyumu ve İşten Ayrılma Niyeti İlişkileri: Kadın Mutfak Çalışanları Örneği
}

Hilal ÖZ, Bilim Uzmanı, Mersin Üniversitesi, Sosyal Bilimler Enstitüsü, Mersin, eposta:ozhla19@gmail.com

ORCID: https://orcid.org/0000-0001-7972-4084

\section{Dr. Beril DÖNMEZ*}

Doç. Dr. Gürkan AKDAĞ, Mersin Üniversitesi, Turizm Fakültesi, Mersin, e-posta: gurkanakdag@mersin.edu.tr

ORCID: https://orcid.org/0000-0001-9819-9465

\section{Öz}

Günümüzde, cinsel taciz, iş hayatında sıklıkla karşılaşılan bir problemdir. Bu sebepten, cinsel tacizin toplumsal etkileri hakkında birbirinden farklı pek çok araştırma literatürde yer almaktadır. Ancak, otel mutfak çalışanlarına yönelik gerçekleştirilen cinsel tacizler ve bu tacizlerin çalışanın iş doyumu ve işten ayrılma niyeti üzerindeki etkisini inceleyen yeterli sayıda araştırma olmaması konunun orijinalliğini betimleyen en önemli unsurlardandır. Araştırmada kullanılan ölçek literatürde daha önceden gerçekleştirilen bilimsel çalışmalardan yola çıkılarak hazırlanmıştır. Otel mutfaklarında çalışan kadın personellerin maruz kaldığı cinsel tacizin, iş tatmini ve işten ayrılma niyetleri arasındaki ilişkinin incelenmesi araştırmanın temel amacını oluşturmaktadır. Bu amaç doğrultusunda; Türkiye'de farklı bölgelerde faaliyet gösteren otel işletmelerinde aktif olarak çalışmakta olan kadın işgörenler ile anket formu aracılığı ile veriler toplanmıştır. Anketlerin tasnif edilmesi sonrası toplam 400 geçerli anket üzerinden analizler gerçekleştirilmiştir. Çalışma sonucunda elde edilen bulgular neticesinde; iş yerinde ortaya çıkan cinsel tacize ilişkin davranışların kadınların iş doyumu, iş performansı ve iş ile ilişkin olumlu algılarını olumsuz olarak etkilediği ve kadın çalışanlarda işten ayrılma niyeti algısını yükselttiği sonucuna ulaşılmıştır.

*Dr. Beril DÖNMEZ' in aziz hatırasına...

Anahtar Kelimeler: Cinsel Taciz, İş Doyumu, İşten Ayrılma Niyeti.

Makale Gönderme Tarihi: 23.07.2020

Makale Kabul Tarihi: 06.10.2020

\section{Önerilen Atıf:}

Öz, H., Dönmez, B. ve Akdağ, G. (2020). İş Yerinde Cinsel Taciz ile İş Doyumu ve İşten Ayrılma Niyeti İlişkileri: Kadın Mutfak Çalışanları Örneği, Türk Turizm Araştırmaları Dergisi, 4(4): 3842-3854.

(c) 2020 Türk Turizm Araştırmaları Dergisi. 


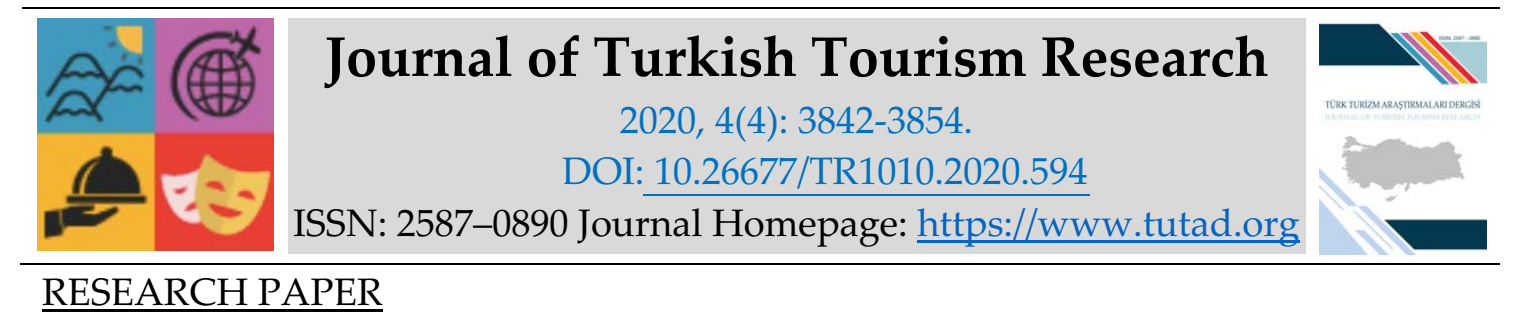

The Relationships of Sexual Harassment at the Workplace, Job Satisfaction and
Turnover Intention: The Example of Female Kitchen Workers

Hilal ÖZ, MSc., Mersin University, Social Sciences Institute, Mersin, e-mail: ozhla19@gmail.com ORCID: https://orcid.org/0000-0001-7972-4084

\title{
Dr. Beril DÖNMEZ*
}

Associate Prof. Dr. Gürkan AKDAĞ, Mersin University, Faculty of Tourism, Mersin, e-mail: gurkanakdag@mersin.edu.tr

ORCID: https://orcid.org/0000-0001-9819-9465

\begin{abstract}
Nowadays, sexual harassment occurs frequently in all areas of business life. For this reason, there are many different studies about the social scale of sexual harassment in the literature. However, this research has been carried out because there are not enough studies investigating the effects of sexual harassment against hotel kitchen workers and the effects of these harassment on job satisfaction and intention to leave. The scale used in the research was prepared based on previous scientific studies in the literature. The aim of this study is to investigate the relationship between sexual harassment, job satisfaction and turnover intention. In accordance with this purpose; data through actively with the female employee who works in business hotels operating in the questionnaire were collected from different regions in Turkey. After the questionnaires were classified, analyzes were carried out on a total of 400 valid questionnaires. As a result of the findings obtained at the end of the study; It was concluded that sexual harassment-related behaviors in the workplace negatively affected women's job satisfaction, job performance and positive perceptions about the job and increased the perception of the intention to leave among female employees.
\end{abstract}

Keywords: Sexual Harassment, Job Satisfaction, Turnover Intention.

Received: 23.07 .2020

Accepted: 06.10.2020

\section{Suggested Citation:}

Öz, H., Dönmez, B. and Akdağ, G. (2020). The Relationships of Sexual Harassment at the Workplace, Job Satisfaction and Turnover Intention: The Example of Female Kitchen Workers, Journal of Turkish Tourism Research, 4(4): 3842-3854.

(C) 2020 Türk Turizm Araştırmaları Dergisi. 


\section{Gíriş}

Cinsel taciz toplumsal hayatta bireylerin maruz kaldığı en bilinen gayri ahlaki davranışlar arasındadır. Toplumsal hayatın bu önemli problemi, iş hayatı açısından da sıklıkla karşılaşılan ve insanları iş hayatından soğutan bir durum olarak kabul edilmektedir. Cinsel tacizle, çalışma hayatında daha çok kadın işgörenlerin karşı karşıya kaldığı bilinmekle birlikte, farklı cinsel tercihe sahip bireylerin de iş hayatında cinsel tacize sıklıkla maruz kaldıkları bilinmektedir. Literatür incelendiğinde, cinsel tacize uğrayan kadın işgörenlerin pek çoğunun benzer davranışlar sergiledikleri görülmektedir. Genel olarak kadınlar; kişisel, örgütsel, kültürel ya da toplumsal nedenlerle uğradıkları tacizi dile getirmemeye özen göstermekte ve bu durumu yok saymaya çalışmaktadırlar. Bu hareketin temelinde ise dile getirilecek taciz sebebiyle toplumsal açıdan yargılanma korkusu ve iş hayatında örgütsel açıdan desteklenmeyeceğine yönelik inancın varlığı bulunmaktadır. Bu yanlış inanç sebebiyle birçok kadın cinsel tacize boyun eğip, bu duruma katlanmak zorunda kalmakta ya da cinsel tacize son vermek adına kendi çözüm yollarını kendisi bulmak durumunda kalmaktadır.

Cinsel taciz, sadece tacize maruz kalan bireyleri ilgilendiren bir sorun olarak görülse de bu durum özellikle tacize uğrayan kadınların bedensel ve zihinsel sağlıklarını bozmaktadır. Cinsel tacize uğrayan kişiler, uzun vadede sosyal hayat içerisinde sağlıklı ilişkiler kuramamakta ve toplumsal hayatta diğer insanlarla iletişim problemleri yaşamaktadır (Karayel, 2006: 1). Bu mevcut durum işletmeler açısından da her geçen yıl daha fazla riskin ortaya çımasına sebep olmaktadır. İş hayatında var olan cinsel taciz davranışları, örgütlerdeki iletişim ve sosyal hayatı etkilediği gibi iş hayatının etkinlik ve verimliliğini de olumsuz yönde etkilemektedir. Örgüt ikliminin olumsuz etkilenmesine sebep olan cinsel taciz davranışları, bireylerin iş tatmini duygularını azaltmakta, bireylerin örgütsel bağlılığını düşürmekte ve en nihayetinde çalışanların işten ayrılma davranışları sergilemesine sebep olmaktadır. Personel devir hızının, sözü edilen olumsuz durumlar sebebiyle yükselmesi de işletmenin hem entelektüel sermayesine olumsuz yansımakta hem de işletme maliyetlerini artırmaktadır (Mimaroğlu ve Özgen, 2008: 322). Bu sebeplerden dolayı, işletmelerin cinsel taciz davranışları karşısında tavizsiz olmaları son derece önemlidir. Cinsel tacizi önlemek adına alınacak kararlar, işgücü kaybını azaltacak, işletme verimliliğini artıracak ve sağlıklı bir iş iklimi yaratılmasına olanak sağlayacaktır (Kömürcü, 2011: 3).

İşverenler tarafından iş yerlerinde güven unsurunun sağlanması, işgörenlerin ruhsal ve bedensel sağlıkları açısından çok önemlidir. Aksi takdirde işletmelerin imajı, verimliliği ve karlılığı azalacaktır. Ancak, tüm bu hassasiyetlere rağmen günümüzde hala iş yerlerinde cinsel taciz vakaları son derece yaygındır. Birçok işveren bu durumu görmezden gelmekte, hatta daha ileriye giderek sırf işletme imajı zedelenmesin diye bu duruma maruz kalan deneyimli çalışanını kaybetmeyi göze alabilmektedir. İş yerinde tacize maruz kalan kadın çalışanların, işten ayrılma niyeti algıları yükselmekte ve iş doyumları da cinsel taciz dolayısıyla azalmaktadır. Bunun sonucunda işveren açısından böyle bir durumla karşı karşıya gelinmesi, örgüt içinde maddi ve manevi kayıplara neden olabilmektedir. İş yerinde cinsel tacize maruz kalan kadın bireyler, sosyal yaşamlarında ve iş yaşamlarında psikolojik açıdan baskı altında hissedebilmektedirler. Tüm bu etmenler sebebiyle; dışlanma, itibar ve güven kaybı, işten duyulan memnuniyetsizlik, işe karşı verimsizlik vb. duygular ortaya çıkabilmektedir. Literatürde, iş hayatında ortaya çıkan cinsel taciz vakaları ile ilgili birçok çalışma mevcut olmasına rağmen, günümüzde hala sıklıkla görülen cinsel taciz olayları, konu üzerinde daha fazla araştırmaların yapılması gerekliliğini ortaya koymaktadır (Şahin, Aydın ve Sarı, 2012: 69). 


\section{KAVRAMSAL ÇERÇEVE}

\section{Cinsel Taciz Kavramı}

Literatürde Cinsel taciz kavramı ile ilgili ilk çalışmalardan birisi Mac Kinnon'ın "Sexual Harassment of Working Woman-Çalışan Kadına Cinsel Taciz" kitabıdır. Çalışmada, cinsel taciz "cinsel taleplerin, eşit olmayan güç ilişkileri bağlamında istenmeyen şekilde dayatılması" olarak tanımlanmıştır (Sherwyn, Kaufman ve Klausner, 2000: 76). Literatür incelendiğinde; taciz kavramı ve bu perspektifte ortaya çıkan cinsel taciz ile ilgili birçok farklı betimlemenin var olduğu bilinmektedir (Kalhor, 2000: 5). Türk Dil Kurumu Güncel Türkçe Sözlüğe göre taciz, "tedirgin etme, rahatsız etme"; cinsel taciz, "ahlaksızca, ulu orta veya gizlice söz ve davranışlarla karşı cinse eziyet etme, tedirginlik ve sıkıntı verme" ya da "çalışma hayatında ekonomik güç, üst makam veya başka etkili bir göreve sahip olanların, genellikle karşı cinsi ahlak dışı birtakım tutum ve davranışlarla cinsel yönden sıkıntıya sokup rahatsız etmesi" olarak tanımlanmaktadır (TDK, 2017). Oxford İngilizce Sözlüğe göre ise taciz, "saldırgan bir baskıya veya sindirmeye maruz bırakmak"; olarak tanımlanırken cinsel taciz ise "işyerinde veya diğer profesyonel veya sosyal durumlarda, istenmeyen ve uygunsuz cinsel ifadelerin kullanılması veya fiziksel avantaj sağlanması şeklinde karakterize edilen davranış" olarak tanımlamıştır. Longman İngilizce Sözlük tacizi "bir kişiye sık sık rahatsız edici şeyler söyleyerek veya onu tehdit ederek, bireyin hayatını nahoş hale getirmek"; olarak adlandırırken cinsel tacizi ise, "özellikle aynı iş yerinde beraber çalışılan bir kişinin, karşı tarafın istemeyeceği şekilde cinsel yorumlarda bulunması, bakması veya dokunması" olarak betimlemiştir.

Cinsel taciz; "iş performansına makul olmayan bir şekilde müdahale eden, korkutucu, düşmanca, saldırgan bir çalışma ortamı yaratan" veya "istihdam, terfi, prim gibi ayrıcalıklar tanımak üzere teklif edilen" istenmeyen cinsel davranışlar şeklinde de tanımlanabilmektedir (Grant, 1999: 25). Karşıllğı olmayan cinsel talepler, cinsel iyilikler ve cinsel nitelikteki diğer sözel veya fiziksel davranışlar, bazı durumlarda cinsel taciz teşkil edebilmektedir. Cinsel şakalar, istenmeyen cinsel girişimler ve çalışma alanında sergilenen cinsel resimler taciz olarak nitelendirilebilmektedir. Israrlı veya tekrarlanan istekler, ahlaka aykırı yorumlar, müstehcen yazılar yazılması ve bazı durumlarda, bir iş arkadaşının "balım", "bebeğim" veya başka uygunsuz isimlerle çağrılması da cinsel taciz davranışları içerisinde yer almaktır (Laird, 1993: 51). Daha çok iş ortamında yaşanabilen cinsel taciz, iş hayatı açısından her geçen yıl daha fazla problem teşkil eder bir hal alırken; hemen her sektörde ortak bir sorun haline gelmiştir (Mohamad vd., 2020: 19). Cinsel tacize uğrayan işgörenlerde, tacize bağlı olarak ortaya çıkan sağlık sorunları ve psikolojik problemler hem çalışan bireyleri hem de işletmeleri zor durumda bırakmakta bireyler açısından işe yönelik bağlılık azalırken işletmeler açısından da faaliyet gösterilen sektörlerde rekabetçilik azalmaktadır. Taciz sebebiyle bireylerin, iş tatmin düzeyleri ortadan kalkmakta ve işten ayrılma niyetleri baskın bir düşünce haline gelmektedir. Ayrıca tacize bağlı olarak psikolojik açıdan; anksiyete ve depresyon gibi strese bağlı reaksiyonlar ve sağlık açısından baş ağrıları, gastrointestinal bozukluklar ve uyku problemleri gibi sonuçlar ortaya çıkmaktadır (Fitzgerald vd., 1997: 579).

\section{İş Doyumu Kavramı}

İş, kişilerin ekonomik, psikolojik ve sosyal ihtiyaçlarını elde etmelerine imkan sağlayan faaliyetler bütünüdür (Yıldırım, 2007: 254). Doyum ise bireylerin karşılaştıkları durumlara karşı verdikleri duygusal tepkiler olarak tanımlanmaktadır. Çalışanların iş hayatı boyunca; birtakım hüzünleri, mutlulukları, kazandıkları ya da kaybettikleri durumlar olmaktadır. Tüm beceri ve duygularının sonunda; iş görenler faaliyet gösterdikleri iş ve bağlı olduğu örgüte yönelik bir 
davranış/tutum kalıpları sergilemektedir. Çalışanların, sergiledikleri iş performansları neticesinde iş ile ilgili fiziksel ya da zihinsel açıdan iyi durumda olmaları da iş doyumlarını ortaya koymaktadır (Yurcu, 2014: 52). Literatür incelendiğinde, konu ile ilgilenen pek çok bilim insanının iş doyumu hakkında temel olarak üç ayırt edici özelliği vurguladıkları görülmektedir. İş doyumu, iş ile ilgili çok sayıda tutumdan meydana gelir. Diğer bir ifadeyle, iş görenler işin belirli boyutlarına karşı olumlu tutumlara sahipken, diğerlerine karşı olumsuz tutumlara sahip olabilirler. Ayrıca iş doyumu, iş ortamında oluşan durumlara karşı bir çeşit duygusal tepkidir, bu nedenle görülemez, yalnızca hissedilebilir. İş doyumunun derecesi, genellikle çıktıların, beklentileri ne ölçüde karşıladığı ile ilgilidir (Vroom, 1964; Smith; 1969; Locke, 1976; Baş, 2002: 19). Demografik (yaş, cinsiyet, eğitim vb.) özellikler, işin içeriği, ücret politikası, yönetim yaklaşımları, çalışma koşulları, ekip arkadaşları gibi örgütsel ve çevresel faktörler iş doyumu üzerinde son derece etkilidir (Ertürk ve Keçecioğlu, 2012: 43).

İş doyumu, iş görenin işini ya da işteki tecrübelerini temel alan olumlu ve pozitif ruh hali, işten aldığı mutluluk, işinden beklentisi ve işinden sağladığı faydalar arasındaki uyum, işe karşı geliştirilen tutum olarak da ifade edilmektedir (Efeoğlu ve Özgen, 2007: 239). Çalışanın iş doyumu doğrudan iş performansını da etkileyen bir unsurdur. Bu açıdan değerlendirildiğinde; işgörenler iş ile ilgili operasyonlarda doyuma ulaşamadıkları durumlarda hayal kırıklığı yaşamakta ve bu durum işlerine karşı soğukluk, işini eksik yapma, işe devamsızlık, işten ayrılma gibi faktörlerin ortaya çıkmasına da sebep olmaktadır (Sayg1, 2016: 35). İşgörenlerin yaptıkları işlerden bekledikleri doyum düzeyi, faaliyet gösterdikleri işe göre farklılık göstermektedir. Çalıştıkları iş ne kadar önemli ve değerli ise çalışanların da doyuma ulaşmaları o kadar güç olmaktadır (Özdemir, 2016: 51). Çalı̧̧ma ortamı ve aile hayatından kaynaklı psikolojik iniş-çıkışlar kişilerin hayat kalitesinde önemli rol oynayan unsurlardır. Bu bağlamda, örgüt içinde bireylerin karşılaştıkları gayri ahlaki davranışlar, olumsuz iş ortamları ya da iş ile ilgili yetersizlik ve adaletsizlik hissetmeleri, görevlerini yeterli düzeyde yerine getirememe, tükenmişlik, işe gelmeme, iş değiştirme talebi ve işten ayrılma gibi olumsuz iş davranışlarına temel oluşturmaktadır (Yılmaz ve Öztürk, 2017: 463).

\section{İşten Ayrılma Niyeti}

İşten ayrılma, kişilerin kendi rızalarıyla çalıştıkları işletmeden uzaklaşma eğilimidir (Gaertner, 1999: 479). Bireyler, iş hayatında sık sık olumsuz durumlar ile karşı karşıya kalmaktadırlar. Yine de birçok olumsuz etkenlere rağmen çalıştıkları iş yerlerinden ayrılmadan çalışmalarını devam ettirebilmektedirler. Çalışanların pek çoğu işleriyle ilgili olumsuz hissiyatları sebebiyle işten ayrılma düşüncesine sahip olsalar dahi, bu durum genel olarak düşünce aşamasında kalmakta fiili olarak bu istek davranışa dönüşmemektedir. Ancak her işgören için farklı noktada da olsa; iş/işletme ile ilgili olumsuzlukların birikimi neticesinde bireyler işten ayrılma niyeti düşüncesine kapılabilmektedirler. Örneğin; bir işgörenin yakın bir süreçte işi bırakma düşüncesinde olması işten ayrılma niyeti olarak tanımlanmaktadır. Ancak, birey bu aşamaya gelene kadar yaşadığ 1 olumsuz durumlar ve bu safhalarda meydana gelen birikimler işten ayrılma niyetine yol açan sebeplerdir. Bu sebepler tek başına bireyin işten ayrılma niyetine sebep olmasa dahi üst üste yaşanan olumsuz duygusal kırılmalar çalışanların işten ayrılma niyetine girmesine sebep olmaktadır. Bu açıdan değerlendirildiğinde; işgörenlerin faaliyet gösterdikleri iş yerinden gelecekte ayrılmaya ilişkin bilinçli karar verme arzuları, işten ayrılma niyeti olarak kabul edilmektedir (Eroğlu, Topçu ve Basım, 2018: 125). Başka bir betimleme ile işten ayrılma "işgörenlerin çalıştıkları işletmeden istekli veya isteksiz bir şekilde ayrılmaları" şeklinde de ifade edilmektedir. İşten ayrılma davranışı, çoğunlukla uzun bir süreyi kapsayan, 
farklı olumsuz durumların neticesinde gerçekleşir ve en nihayetinde ortaya çıkan sonuç işten ayrılma niyetidir (Erdirençelebi ve Ertürk, 2018: 606).

İşten ayrılma niyeti, örgütler üzerinde doğrudan ve dolaylı maliyetleri olması nedeniyle oldukça önemli bir konudur. Örgütlerin toplam maliyetleri içinde işten ayrılmaların \%15-30 oranında bir paya sahip olduğu dikkate alındığında, konunun önemi daha iyi anlaşılacaktır (Jang ve George 2012: 590; Tuna ve Yeşiltaş, 2014: 108). İşten ayrılma niyetine etki eden kişisel ve örgütsel birden çok etken bulunmaktadır. Bu etkenlerin işletme tarafından bilinip bunları önlemeye yönelik adımlar atılması hem işgörene hem de işverene olumlu sonuçlar yaratabilmektedir (Aydın, 2018: 36). Literatürde işten ayrılma niyetine etki eden faktörler genel olarak dışsal faktörler (işsizlik oranı, alternatif iş olanakları gibi), örgütsel faktörler (yönetim tarzl, ücret, ödüllendirme gibi) ve kişisel faktörler (kişilik, yaş, aile gibi) olmak üzere üç ana başlık altında sınıflandırılmaktadır (Şahin, 2017: 279).

\section{YÖNTEM}

Nicel araştırma deseni ile tasarlanan çalışma, tarama modeliyle oluşturulmuştur. Model kapsamında, tekil ve ilişkisel tarama yöntemleri tercih edilmiştir. Bu kapsamda öncelikle; cinsel taciz, iş doyumu ve işten ayrılma niyeti ile ilgili ayrıntılı literatür taraması gerçekleştirilip sonrasında teorik çerçeve oluşturulmuştur. Veri toplama aracı olarak, (Fitzgerald vd., 1999) tarafından geçerliliği ve güvenirliği kanıtlanmış ve önceki araştırmalarda kullanılmış cinsel taciz ölçeği kullanılmıştır. İşten ayrılma niyeti için Polat ve Meydan (2010) ve Dalmış (2018) tarafından kullanılan işten ayrılma niyeti ölçeğinden yararlanılmıştır. Son olarak iş doyumu ölçeği için Judge ve diğerleri (1998) tarafından geliştirilen orijinal ölçek kullanılmıştır. 20 maddelik cinsel taciz ölçeği, 5 maddelik iş doyumu ve 5 maddelik işten ayrılma niyeti ölçeği, 5'li Likert derecelendirmeye uygun şekilde hazırlanmıştır.

Araştırmanın evrenini otel mutfaklarındaki kadın çalışanlar oluşturmaktadır. Elde edilen veriler otel mutfaklarındaki kadın çalışanlardan anket yardımıyla toplanmıştır. Çalışmada, sınırsız evren örnekleme formülü kullanılmıştır. Araştırmanın amacına ve araştırma sorularına uygun olarak örnekleme dahil edilen kadın çalışanların demografik özelliklerine ulaşabilmek için tanımlayıcı istatistikler kullanılmıştır. Anketler, otel mutfaklarındaki kadın çalışanlara, kolayda örnekleme yöntemi ile uygulanmıştır. Araştırma verilerinin analizinde SPSS 21.0 istatistik paket programından yararlanılmıştır. Analizlerde öncelikle, frekans ve yüzde gibi tanımlayıcı istatistikler kullanılmıştır. Analize geçmeden önce, veriler açıklayıcı faktör analizine tabi tutulmuş son olarak da işten ayrılma niyeti, iş doyumu ve cinsel taciz boyutları arasındaki ilişkiyi ölçebilmek adına korelasyon analizi gerçekleştirilmiş̧ir.

\section{BULGULAR}

Katılımcıların demografik özellikleri incelendiğinde; yaş grupları açısından kadın işgörenlerin \%23,3'ü 21-25 yaş, \%20'si 26-30 yaş aralığındadır. Araştırmaya katılan katılımcıların \%11,5'i 1820 yaş aralığındadır. Bu sonuçlar, katılımcı grubunun ağırlıklı olarak aktif olarak çalışmakta olan genç işgörenlerden oluştuğunu göstermektedir. İşgörenlerin eğitim durumları incelendiğinde; kadın çalışanların \%34,1'i lisans mezunu \%32,6'sı lise mezunu \%19,7'si ise ön lisans mezunudur. Sektörde rastlanılan "alaylı" mutfak personeli akımının aksine, mutfakta görev alan kadın işgörenlerin ağırlıklı olarak eğitim seviyelerinin yüksek olduğunu söylemek mümkündür. Medeni durum açısından incelendiğinde kadın işgörenlerin \%72,6'sının bekar, $\% 26,9^{\prime}$ unun ise evli olduğu bulgulanmıştır. Son olarak; araştırmaya katılan kadın işgörenlerin 
\%37,4'ü Adana, \%18,2'si Antalya, \%14,4'ü Kuşadası, \%13,6'sı İstanbul, \%11,5'i Bodrum ve $\% 4,9^{\prime}$ unun Hatay ilinde aktif olarak iş hayatında yer aldıkları bulgulanmıştır.

Tablo1. Katılımcıların Demografik Özelliklerine İlişkin Bulgular

\begin{tabular}{|c|c|c|c|c|c|}
\hline Gruplar & $f$ & $\%$ & Gruplar & $\mathrm{f}$ & $\%$ \\
\hline \multicolumn{3}{|c|}{ Yaş } & \multicolumn{3}{|c|}{ Eğitim Durumu } \\
\hline 18'den küçük & 33 & 8,5 & İlkokul & 9 & 2,3 \\
\hline $18-20$ yaş & 45 & 11,5 & Ortaokul & 15 & 3,8 \\
\hline $21-25$ yaş & 91 & 23,3 & Lise & 127 & 32,6 \\
\hline $26-30$ yaş & 78 & 20,0 & Ön Lisans & 77 & 19,7 \\
\hline $31-35$ yaş & 42 & 10,8 & Lisans & 133 & 34,1 \\
\hline $36-40$ yaş & 39 & 10,0 & Yüksek Lisans & 22 & 5,6 \\
\hline $41-45$ yaş & 35 & 9,0 & Doktora & 1 & 3 \\
\hline $46-50$ yaş & 9 & 2,3 & Toplam & 385 & 98,7 \\
\hline $51-55$ yaş & 4 & 1,0 & \multicolumn{3}{|c|}{ Yașanılan Şehir } \\
\hline $56-60$ yaş & 3 & 8 & Adana & $146^{3}$ & 37,4 \\
\hline Toplam & 379 & 97,2 & Antalya & 71 & 18,2 \\
\hline \multicolumn{3}{|c|}{ Medeni Durum } & Bodrum & 45 & 11,5 \\
\hline Bekâr & 283 & 72,6 & Hatay & 19 & 4,9 \\
\hline Evli & 105 & 26,9 & İstanbul & 53 & 13,6 \\
\hline \multirow[t]{2}{*}{ Toplam } & 388 & 99,5 & Kuşadası & 56 & 14,4 \\
\hline & & & Toplam & 390 & 100,0 \\
\hline
\end{tabular}

Tablo2. İşten Ayrılma Niyeti Faktör Analizi

\begin{tabular}{|c|c|c|c|c|c|c|}
\hline & $\begin{array}{l}\text { Faktör } \\
\text { Yükü }\end{array}$ & Özdeğer & Varyans & Alfa & Ort. & $\begin{array}{c}\text { Std. } \\
\text { Sapma }\end{array}$ \\
\hline İşten Ayrılma Niyeti & & 2,301 & 46,014 & 703 & 3,0649 & 83816 \\
\hline $\begin{array}{l}\text { 4. Başka işletmelerde iş bulma } \\
\text { olanağım olup olmadığına } \\
\text { bakıyorum. }\end{array}$ & ,742 & & & & & \\
\hline $\begin{array}{l}\text { 2. Önümüzdeki yıllarda başka } \\
\text { bir işletmede çalışmayı } \\
\text { düşünüyorum. }\end{array}$ & ,720 & & & & & \\
\hline $\begin{array}{l}\text { 5. Sık sık işten ayrılmayı } \\
\text { düšunüyorum. }\end{array}$ & 693 & & & & & \\
\hline $\begin{array}{l}\text { 1. Bu işletmede önümüzdeki } \\
\text { yıllarda da çalışmak isterim. }\end{array}$ & ,665 & & & & & \\
\hline $\begin{array}{l}\text { 3. Çoğu zaman iyi bir işim } \\
\text { olduğunu düşünüyorum. }\end{array}$ & ,556 & & & & & \\
\hline \multicolumn{7}{|c|}{$\begin{array}{l}\text { Faktör çıarma metodu: Temel bileşenler analizi; Kaiser-Meyer-Olkin Örneklem Yeterliliği: } \\
\text { \%64,1; } \\
\text { Bartlett's Küresellik Testi için Ki-Kare: } 458,196 \text { s.d:10 p<0.0001; } \\
\text { Açılanan toplam varyans: \%46,014; Ölçeğin tamamı için güvenirlik katsayısı: ,703 } \\
\text { Tepki kategorileri: 1: Hiç katılmıyorum,...5:Kesinlikle katıllyorum }\end{array}$} \\
\hline
\end{tabular}

Demografik özelliklerin analiz edilmesinden sonra çalışmada verilerin faktör temelli dağılımları gerçekleştirilmiştir. Üç ölçek için de faktör analizi uygulanmış ve faktör dağılımları tespit 
edilmiştir. Gerçekleştirilen analizler neticesinde; cinsel taciz ölçeği iki faktör altında toplanırken; işten ayrılma niyeti ve iş doyumu ölçekleri tek faktör altında toplanmıştır. İşten ayrılma niyeti ölçeğine uygulanan faktör analizi sonuçları tablo 2'de verilmiştir. Analiz sonucunda KMO örneklem yeterliliğinin \%64,1 olduğu ve Bartlett's Küresellik Testinin de (KiKare: 458,196 s.d:10 p<0.0001) anlamlı olduğu tespit edilmiştir. Bu iki sonuç ölçeğin faktör analizine uygunluğunu göstermektedir. Oluşan tek faktör toplam varyansın \% $46^{\prime}$ sını açıklamaktadır.

Tablo 3 iş doyumu ölçeğine uygulanan faktör analizi sonucunu göstermektedir. Analiz sonucunda KMO örneklem yeterliliği \%80 olarak hesaplanmıştır. Bartlett's Küresellik Testinin de (Ki-Kare: 1392,410s.d:6 p <0.0001) anlamlı olduğu tespit edilmiştir. Bu iki sonuç faktör analizine uygun olduğunu göstermektedir. Yapı tek faktörden oluşmakta ve toplam varyansın $\% 56$ 'sını açıklamaktadır.

Tablo 3. İş Doyumu Faktör Analizi

\begin{tabular}{|c|c|c|c|c|c|c|}
\hline & $\begin{array}{l}\text { Faktör } \\
\text { Yükü }\end{array}$ & Özdeğer & Varyans & Alfa & Ort. & $\begin{array}{c}\text { Std. } \\
\text { Sapma }\end{array}$ \\
\hline İş Doyumu & & 3,337 & 56,816 & ,933 & 3,6917 & 1,05453 \\
\hline $\begin{array}{lll}\begin{array}{l}\text { 2.Genel } \\
\text { seviyorum. }\end{array} & \text { olarak } & \text { işimi } \\
\end{array}$ & 941 & & & & & \\
\hline $\begin{array}{l}\text { 1.Genel olarak işimden } \\
\text { memnunum. }\end{array}$ & ,922 & & & & & \\
\hline $\begin{array}{l}\text { 3.Toplum içinde (örneğin } \\
\text { ofiste) veya sizinle baş } \\
\text { başayken kaba veya rahatsız } \\
\text { edici imalarda bulunulması }\end{array}$ & 895 & & & & & \\
\hline 4. İşimden zevk alıyorum. & 894 & & & & & \\
\hline \multicolumn{7}{|c|}{$\begin{array}{l}\text { Faktör çıkarma metodu: Temel bileşenler analizi; Kaiser-Meyer-Olkin Örneklem Yeterliliği: \%80; } \\
\text { Bartlett's Küresellik Testi için Ki-Kare: 1392,410s.d:6 p<0.0001; } \\
\text { Açıklanan toplam varyans: \%46,014; Ölçeğin tamamı için güvenirlik katsayısı: ,933 } \\
\text { Tepki kategorileri: 1: Hiç katılmıyorum, ...5:Kesinlikle katılıyorum }\end{array}$} \\
\hline
\end{tabular}

Cinsel taciz ölçeğine uygulanan faktör analizi sonuçları tablo 4 üzerinde gösterilmektedir. Faktör analizi gerçekleştirilirken binişik madde özelliği taşıyan maddeler analizden çıkartılmış ve analizler 18 madde üzerinden gerçekleştirilmiştir. Faktör analizi neticesinde, cinsel baskı ve cinsel taciz eğilimi olmak üzere cinsel taciz ölçeği iki boyuttan oluşmuştur.

Analizde, KMO örneklem yeterliliği \%94,9 olarak hesaplanmıştır ve Bartlett's Küresellik Testi de (Ki-Kare: 1392,410 s.d:153 p<0.0001) anlamlıdır. Dolayısıyla ölçek faktör analizi için uygundur. Ortaya çıkan iki boyutlu yapı varyansın \%78'sini açıklamaktadır. "cinsel baskı" olarak isimlendirilen ilk faktör 9 maddeden oluşmakta ve toplam varyansın \%39'unu açılamaktadır. İkinci faktör de 9 maddeden oluşmakta, toplam varyansın \%38'ini açıklamaktadır ve "cinsel taciz" şeklinde isimlendirilmiştir.

Faktör analizleri sonrası değişkenler arası ilişkileri tespit edebilmek ve çalışmanın hedefleri doğrultusunda çıarımlarda bulunabilmek adına korelasyon analizi gerçekleştirilmiştir. İşten ayrılma niyeti, iş doyumu ve cinsel taciz boyutları arasındaki ilişkiyi gösteren korelasyon analizi Tablo 5 üzerinde detaylandırılmıştır. Gerçekleştirilen korelasyon analizi neticesinde işten ayrılma niyeti ile cinsel tacizin birinci boyutu (cinsel baskı) arasında pozitif yönlü ve istatistiki açıdan zayıf derecede anlamlı bir ilişki bulunmaktadır. Yani bireylerin maruz kaldıkları cinsel taciz ile ilişkili davranışlar kadın işgörenlerin işten ayrılma eğilimlerini arttırmakta, kadınlar işe ve iş yerine karşı negatif turum içine girmektedirler. 
Tablo 4. Cinsel Taciz Ölçeği Faktör Analizi

\begin{tabular}{|c|c|c|c|c|c|c|}
\hline & $\begin{array}{c}\text { Faktör } \\
\text { Yüküu }\end{array}$ & Özdeğer & Varyans & Alfa & Ort. & Std. Sapma \\
\hline Cinsel Baskı & & 7,108 & 77,585 & ,964 & 1,7175 & 1,02714 \\
\hline $\begin{array}{lrr}\text { 16.Cinsel taleplerine } & \text { olumlu } & \text { yanıt } \\
\text { vermeniz durumunda işyerinizde } & \text { daha } \\
\text { hızlı yükseleceğinizi ima etmesi } & \end{array}$ & ,920 & & & & & \\
\hline $\begin{array}{l}\text { 17.İşyerinizde iyi muamele görmeniz için } \\
\text { cinsel davetleri olumlu cevaplamanız } \\
\text { gerektiğini hissettirmesi }\end{array}$ & ,917 & & & & & \\
\hline $\begin{array}{l}\text { 18.Cinsel taleplerine olumsuz yanit } \\
\text { vermeniz durumunda işyerinizde size } \\
\text { kötü muamele edileceği konusunda } \\
\text { gözünüzü korkutması }\end{array}$ & ,900 & & & & & \\
\hline $\begin{array}{l}\text { 15.Sizi, fiziksel savunmaya geçirecek } \\
\text { şekilde istemediğiniz türde bir cinsel } \\
\text { ilişkiye girmek üzere girişimlerde } \\
\text { bulunmas1 }\end{array}$ & ,853 & & & & & \\
\hline $\begin{array}{l}\text { 19.Erkek müdürünüz veya çalışma } \\
\text { arkadaşınız ile cinsel münasebete girmeyi } \\
\text { reddettiğiniz için size kötü davranması }\end{array}$ & 840 & & & & & \\
\hline $\begin{array}{l}\text { 12. Cinsel taleplerine olumlu yanit } \\
\text { vermediğiniz için sizden intikam almak } \\
\text { üzere tehdit altında hissetmenizi } \\
\text { sağlaması }\end{array}$ & ,771 & & & & & \\
\hline $\begin{array}{l}\text { 11.Cinsel münasebette bulunmak için } \\
\text { sanki ödül almak veya özel muamele } \\
\text { görmek istiyormuşsunuz gibi hissettirmesi }\end{array}$ & ,768 & & & & & \\
\hline $\begin{array}{l}\text { 14.İstemediğiniz türde bir dokunma ya da } \\
\text { okşamaya teşebbüs etmesi }\end{array}$ & 698 & & & & & \\
\hline $\begin{array}{l}\text { 13.Kendinizi huzursuz hissedeceğiniz } \\
\text { şekilde size temas etmesi }\end{array}$ & 671 & & & & & \\
\hline Cinsel Taciz Eğilimi & & 6,857 & 77,585 & 954 & 2,3727 & 1,17354 \\
\hline $\begin{array}{l}\text { 4. D1ş görünüşünüz, vücudunuz veya } \\
\text { cinsel aktiviteleriniz hakkında rahatsız } \\
\text { edici imalarda bulunması }\end{array}$ & ,876 & & & & & \\
\hline $\begin{array}{l}\text { 2. Kişisel veya cinsel konular hakkında sizi } \\
\text { tartısmaya çekecek istenmeyen } \\
\text { davranışlarda bulunması }\end{array}$ & ,873 & & & & & \\
\hline $\begin{array}{l}\text { 3.Toplum içinde veya sizinle baş başayken } \\
\text { kaba veya rahatsı edici imalarda } \\
\text { bulunması }\end{array}$ & 861 & & & & & \\
\hline 1.Genellikle açık saçık hikâyeler anlatması & 854 & & & & & \\
\hline $\begin{array}{l}\text { 5.İstemediğiniz bir biçimde size yönelik } \\
\text { cinsel ilgi göstermesi }\end{array}$ & 821 & & & & & \\
\hline $\begin{array}{l}\text { 6.Sizi huzursuz hissettirecek şekilde kötü } \\
\text { niyetli, şehvetli bakışlar atması }\end{array}$ & ,772 & & & & & \\
\hline 9.Sık sık cinsiyetçi yorumlar yapması & ,718 & & & & & \\
\hline $\begin{array}{l}\text { 7.Engelleme çabalarınıza rağmen sizinle } \\
\text { bir ilişki yaşamak için uğraşması }\end{array}$ &, 710 & & & & & \\
\hline $\begin{array}{l}\text { 8.Cinsiyetçi veya açık saçık materyaller } \\
\text { göstermesi }\end{array}$ & 672 & & & & & \\
\hline \multicolumn{7}{|c|}{$\begin{array}{l}\text { Faktör çıkarma metodu: Temel bileşenler analizi; Kaiser-Meyer-Olkin Örneklem Yeterliliği: \%94,9; } \\
\text { Bartlett's Küresellik Testi için Ki-Kare: } 1392,410 \text { s.d:153 p<0.0001; } \\
\text { Açıklanan toplam varyans: \%77,585; Ölçeğin tamamı için güvenirlik katsayısı: ,965 } \\
\text { Tepki kategorileri: 1: Hiç katılmıyorum,...5:Kesinlikle katıllyorum }\end{array}$} \\
\hline
\end{tabular}


Tablo 5. İşten Ayrılma Niyeti, İş Doyumu ve Cinsel Taciz Boyutları Arasındaki İlişki

\begin{tabular}{|l|l|l|l|l|}
\hline & $\begin{array}{l}\text { İşten Ayrılma } \\
\text { Niyeti }\end{array}$ & İş Doyumu & Cinsel Baskı & \multicolumn{1}{c|}{$\begin{array}{c}\text { Cinsel Taciz } \\
\text { Eğilimi }\end{array}$} \\
\hline Cinsel Taciz &, $103^{*}$ &,$- 217^{* *}$ &, $684^{* *}$ & 1 \\
\hline Cinsel Bask1 &, $139^{* *}$ &,$- 129^{*}$ & 1 & \\
\hline İş Doyumu &,$- 348^{* *}$ & 1 & & \\
\hline İssten Ayrılma Niyeti & 1 & & & \\
\hline \multirow{2}{*}{${ }^{* *}$ Correlation is significant at the 0.01 level (2-tailed). } \\
\hline
\end{tabular}

Ayrıca iş doyumu ile cinsel tacizin ikinci boyutu (Cinsel taciz eğilimi) arasında negatif yönlü düşük seviyede anlamlı bir ilişki olduğu tespit edilmiştir. Bu durum da bireylerin cinsel tacizi andıran davranışlar ya da olumsuz yaklaşımlar ile karşı karşıya kaldıkları durumlarda işlerine yönelik algılarının da negatif etkilendiği ve kadın işgörenlerin iş doyumu algılarının söz konusu durumdan olumsuz etkilendiğini ortaya koymaktadır. İş yerinde meydana gelen her türlü cinsel baskı ya da cinsel tacizi kapsayan davranış kadınların iş doyumu ve iş ile ilgili olumlu tutumları üzerinde negatif etkiler yaratmaktadır. Söz konusu durumun uzun vadeli yoğunluğu ise çalışanlarda işten ayrılma niyeti oluşmasına ve son noktada ise kadın işgörenlerin işten ayrılmasına sebep olmaktadır.

\section{SONUÇ ve ÖNERİLER}

Cinsel taciz kavramı, iş hayatında kadınların her geçen yıl daha fazla yer almaya başlamasıyla birlikte sıklıkla duyulmaya başlanan ve kadınları iş hayatından soyutlayan olumsuz davranışların en önde gelenlerinden biridir. Bireylerin çalıştıkları işlere yabancılaşmaları, işten soğumaları ve en nihayetinde işten ayrılmaya kadar giden davranışlarda bulunmalarına sebep olan cinsel taciz hem ahlaki hem de yönetimsel bir sorun olarak kabul edilmektedir. Bu çalışma, Türkiye'de farklı coğrafyalarda bulunan otel işletmelerinde aktif olarak çalışmakta olan kadın işgörenlerin çalıştıkları iş yerlerinde maruz kaldıkları tacizlere ilişkin sergiledikleri davranışları ortaya çıkarmak hedefiyle hazırlanmıştır. Gerçekleştirilen analizler neticesinde; kadın işgörenlerin iş yerlerinde sözlü ya da fiziksel anlamda tacizlere sıklıkla maruz kaldıkları sonucuna ulaşılmıştır. Kadın işgörenlerin maruz kaldıkları bu gayri ahlaki davranışların ise kadınların çalıştıkları iş yeri ve mesleklerine ilişkin tutumlarını negatif yönde etkilediği çalışma bulguları ile istatistiki olarak kanıtlanmıştır. Cinsel tacize maruz kalan kadın çalışanların iş doyum düzeyleri düşük, işten ayrılma niyetleri ise yüksek düzeyde ortaya çıkmaktadır. Ankete katılan kadın çalışanların hepsi en az bir taciz ifadesine maruz kaldıklarını beyan etmişlerdir.

Hemen hemen her sektörde karşılaşılabilen bir sorun olan cinsel taciz, otel mutfaklarındaki kadın bireyleri hem sosyal hem de psikolojik açıdan etkilemektedir. Tacize maruz kalan kadın bireyler iş ortamında kendilerini baskı altında hissetmekte, yaşadıkları taciz durumlarından ötürü iş tatminleri tamamen ortadan kalkmakta ve işten ayrılma niyetleri yükselmektedir. Ancak söz konusu durum iş yerleri açısından incelendiğinde; işletmelerin kendi çıkar ve imajlarını ön planda tutarak isimlerinin zedelenmemesi için cinsel taciz gibi hoş olmayan durumların ortaya çıkarılmasından yana olmadıkları sonucuna da ulaşılmıştır. İşletmelerin taciz olaylarında ciddi bir politikalarının olmayışı ve işletmenin çıkarlarının her şeyden önde olması, işletme içi bu tarz olayların genelde kapatılmak istenmesi, kimi zaman da tacizde bulunan bir müşterinin bile hoş görülebilmesi cinsel tacizin örtbas edildiği dramatik örnekler olarak literatürde yer almaktadır. 
Cinsel tacize varan gayri ahlaki davranışlar birçok sektörde yaşanabilmektedir. Fakat, önemli olan bu olayların yaşanmaması ya da en aza indirgenmesi ve önlenebilmesi için çeşitli plan ve stratejilerin belirlenmesi gerekliliğidir. Bu bağlamda, kanun koyucuların cinsel taciz ve benzeri suçlara ilişkin yaptırımları arttırması son derece önem arz etmektedir. Diğer yandan işverenlerin ya da işletme yöneticilerinin, cinsel tacizi önleyici politikalar geliştirmesi ve tacizi gerçekleştiren kişiler için cezai yaptırımlar uygulanması yönünde tutum geliştirmeleri de gerekmektedir. Tacize maruz kalan kadın işgörenlerin de bu durumu kapatmak yerine ortaya çıkarmaları, kendilerine ait yasal hakları kullanarak gereken müdahaleyi yapmaları son derece kritik bir yaklaşımdır. Kadınların, kendi yasal hak ve özgürlüklerini bilip, tacize maruz kaldıkları durumlarda adli işlem yaptırmaktan ya da bu girişimde bulunmaktan kaçınmamaları benzer vakaların daha sonraki dönemlerde yeniden ortaya çıkmaması için son derece önemlidir. Cinsel taciz gibi önem arz eden, kişilerin hem fiziksel hem de ruhsal sağlığını tehlikeye düşürüp zedeleyebilecek olayların yaşanmaması için gereken hassasiyetin ve özenin gösterilmesi işletmedeki her bireyin temel sorumlulukları arasındadır. Aksi takdirde; düşük iş doyumuna bağlı olarak, duygusal yıkımlar, bunalımlar, dikkatsizlik gibi sorunlar ortaya çıkabilmektedir. Aynı zamanda; nitelikli bir iş görenin tacize maruz kalıp işten ayrılmasından sonra yerine alınacak yeni bir çalışanın eğitilmesi, işletme için faydalı bir personel haline getirilmesi için gösterilen emek ve zaman, mali açıdan işletme için de zarar oluşturabilmektedir. Dolayısıyla, cinsel tacizin yaşanmaması için gereken tüm önlemlerin işletme tarafından alınması son derece değerlidir.

$\mathrm{Bu}$ çalışma turizm endüstrisinde faaliyet gösteren otel işletmelerinde gerçekleştirilmiştir. Dolayısıyla turizm endüstrisinin farklı sektörlerinde gerçekleştirilecek çalışmalar ile daha farklı sonuçlara ulaşılması olasıdır. Diğer yandan otel işletmelerindeki daha farklı departmanlarda çalışan kadın işgörenler ile de gerçekleştirilecek benzer çalışmalar cinsel taciz davranışının ne denli geniş kapsamlı olabileceği hakkında bilgi verecektir. Son olarak; çalışmanın gerçekleştirildiği otel mutfaklarındaki kadın çalışanların, anket formunu doldururken etkilenebilecekleri çevresel faktörlerin kontrol altında tutulamamasının araştırma bulgularını etkilediği varsayılmaktadır. Otel mutfak yöneticileri veya işletme sahiplerinin farklı nedenlerden dolayı anket formlarının çalışanlara dağıtılmasına izin vermeme durumu, anketlerin topluca doldurulmasını istemeleri ya da kadın çalışanların da farklı sebepler öne sürerek soru formunu doldurmak istememesi gibi davranışlar çalışma kapsamında karşılaşılan en önemli kısıtlar arasındadır. Sözü edilen örnekler, cinsel taciz gibi gayri ahlaki, davranışların istatistiki olarak tespit edilenden çok daha fazla olduğunu örneklemektedir.

\section{KAYNAKÇA}

Aydın, Ö. (2018). Algılanan Örgütsel Destek ile Örgütsel Sinizmin İşten Ayrlma Niyeti Üzerine Etkileri: Atatürk Havalimanı Temsil Gözetim ve Yönetim Hizmetleri Şirketlerine Yönelik Bir Araştırma. Yayımlanmamış Yüksek Lisans Tezi, İstanbul Arel Üniversitesi Sosyal Bilimler Enstitüsü, İstanbul.

Baş, T. (2002). Öğretim Üyelerinin İş Tatmin Profillerinin Belirlenmesi. Dokuz Eylül Üniversitesi İktisadi ve İdari Bilimler Fakültesi Dergisi, 17(2), 19-37.

Dalmış, A. B. (2018). Örgütsel Bağlı̆ı̆̆ın İşten Ayrılma Niyeti ve İş Karşıtı Davranışlar Üzerine Etkisi: Havacılık Sektöründe Bir Araştırma. Yayımlanmamış Doktora Tezi, Türk Hava Kurumu Üniversitesi Sosyal Bilimler Enstitüsü, Ankara. 
Efeoğlu, İ. E. ve Özgen, H. (2006). İş Aile Yaşam Çatışmasının İş Stresi, İş Doyumu ve Örgütsel Bağlllık Üzerindeki Etkileri: İlaç Sektöründe Bir Araştırma. Çukurova Üniversitesi Sosyal Bilimler Enstitüsü Dergisi, 16(2), 237-254.

Erdirençelebi, M. ve Ertürk, E. (2018). Çalışanların Örgütsel Yalnızlık Algısının İş Tatmini ve İşten Ayrılma Niyeti Üzerine Etkileri. Gaziantep Üniversitesi Sosyal Bilimler Dergisi, 17(2), 603617.

Eroğlu, A., Topçu, M. K. ve Basım, H. N. (2018). Bireysel Yenilikçi Davranışların Çalışma Arkadaşları ile Çatışma ve İşten Ayrılma Niyeti Üzerine Etkileri: Kamu Sektöründe Bir Araştırma. Business and Economics Research Journal, 9(1), 123-136.

Ertürk, E. ve Keçecioğlu, T. (2012). Çalışanların İş Doyumları ile Mesleki Tükenmişlik Düzeyleri Arasındaki İlişkiler: Öğretmenler Üzerine Örnek Bir Uygulama. Ege Akademik Bakış, 12(1), 41-54.

Fitzgerald, L. F., Drasgow, F., Hulin, C. L., Gelfand, M. J. and Magley, V. J. (1997). Antecedents and Consequences of Sexual Harassment in Organizations: A Test of an Integrated Model. Journal of Applied Psychology, 82(4), 578-589.

Fitzgerald, L. F., Magley, V., Drasgow, F. and Valdo, C. (1999). Measuring Sexual Harassment in The Military: The Sexual Experiences Questionnaire. Military Psychology 11(3), 243-263.

Gaertner, S. (1999). Structural Determinants of Job Satisfaction and Organizational Commitment in Turnover Models. Human Resource Management Review, 9(4), 479-493.

Grant, S. M. (1999). Incidence and Risk Factors of Sexual Harassment among Working Women: Implications for Counseling Psychology and the Workplace. University of California, Los Angeles.

Judge, T. A., Locke, E. A., Durham, C. C and Kluger, A. N. (1998). Dispositional Effects on Job and Life Satisfaction: The Role of Core Evaluations. Journal of Applied Psychology, 83(1), 17-34.

Jung, J. and George, R. T. (2012). Understanding the Influence of Polychronicity on Job Satisfaction and Turnover Intention: A Study of Non-Supervisory Hotel Employees, International Journal of Hospitality Management, 31: 588-595

Karayel, A. (2006). Reprospektif Bir Çalışma: 2001-2005 Yilları Arasında Adana Il Emniyet Müdürlüğ̈̈ne Yansıyan Cinsel Taciz Vakalarının İncelenmesi. Yayımlanmamış Yüksek Lisans Tezi, Çukurova Üniversitesi Sosyal Bilimler Enstitüsü, Adana.

Kömürcü, S. (2011). Otel İşletmelerinde Çalışan Kadınların Isşten Ayrılma Ĕğilimlerinde İşyerinde Romantizmin Ardılları: Cinsel Tacizin Rolü. Yayımlanmamış Yüksek Lisans Tezi. Dokuz Eylül Üniversitesi Sosyal Bilimler Enstitüsü, İzmir.

Laird, M. J. (1993). Sexual Harassment: A Look to the Future. Management Decision, 31(5), 51-54.

Locke, E. A. (1976). The Nature and Causes of Job Satisfaction, in Dunnette, M. D. (Ed.), Handbook of Industrial and Organizational Psychology, Chicago, IL: Rand Mc Nally.

Mimaroğlu, H. ve Özgen, H. (2005). Örgütlerde Güç Eşitsizlikleri ve Cinsel Taciz. Çukurova Üniversitesi Sosyal Bilimler Enstitüsü Dergisi, 17(1), 321-334.

Mohamad, M. and Suhaimi, S. A. (2020). Measuring an Interaction of Sexual Harassment and Employee Job Satisfaction. Asian Social Science and Humanities Research Journal (ASHREJ), 1(1), 19-26.

Özdemir, Ö. (2016). Turist Rehberlerinde Personel Güçlendirme Uygulamalarının İş Doyumuna Etkisi. Yayımlanmamış Yüksek Lisans Tezi, Balıkesir Üniversitesi Sosyal Bilimler Enstitüsü, Balıkesir. 
Polat, M. ve Meydan, C. H. (2010). Örgütsel Özdeşleşmenin Sinizm ve İşten Ayrılma Niyeti ile İlişkisi Üzerine Bir Araştırma. Savunma Bilimleri Dergisi, 9(1), 145-172.

Sherwyn, D. S. Kaufman, E. A. and Klausner, A. A. (2000). Same-Sex Sexual harassment. The Cornell Hotel and Restaurant Administration Quarterly, 41(6), 75-80.

Smith, P. C., Kendall, L. M. and Hulin, C. L. (1969). The Measurement of Satisfaction in Work and Retirement, Chicago, IL: Rand Mc Nally.

Şahin, M. Aydın, B. Ve Sarı, S. V. (2012). Avm’lerde Çalışan Kadın Satış Danışmanlarının Cinsel Tacize İlişkin Görüşleri. Cumhuriyet International Journal of Education, 1(2), 67-81.

Tuna, M. ve Yeşiltaş, M. (2014). Etik İklim, İşe Yabancılaşma ve Örgütsel Özdeşleşmenin İşten Ayrılma Niyeti Üzerindeki Etkisi: Otel İşletmelerinde Bir Araştırma. Anatolia: Turizm Araştırmaları Dergisi, 25(1), 105-117.

Türk Dil Kurumu-TDK. Taciz. http: //www .tdk. gov. tr/ index. php? Option = com _ gts \& arama=gts\&guid=TDK.GTS.5b6bf354cfc9e3.44171975] adresinden alınmıştır. 20.12.2017

Vroom,V. (1964). Work and Motivation, New York: Willey.

Yeşiltaş, M. (2005). İnsan Kaynakları Yönetimi Açısından Bir Sorun Olarak İşyerinde Cinsel Taciz. Manas Üniversitesi Sosyal Bilimler Dergisi, 13, 147-155.

Yıldırım, F. (2007). İş Doyumu ile Örgütsel Adalet İlişkisi. Ankara Üniversitesi SBF Dergisi, 62(1), 254-278.

Yılmaz, E. ve Öztürk, İ. (2017). Algılanan Örgütsel Adaletin İş Tatminine Etkisinin İncelenmesine Yönelik Akademisyenler Üzerinde Bir Araştırma: Vakıf ve Devlet Üniversitesi Karş1laştırması. Mustafa Kemal Üniversitesi Sosyal Bilimler Enstitüsü Dergisi, 40(14), 461-481.

Yurcu, G. (2014). Konaklama İşletmelerinde Çalışanların Örgütsel Vatandaşlık Davranışlarının Iş̧ Doyumu ve Öznel İyi Oluşlarına Etkisi. Yayımlanmamış Yüksek Lisans Tezi, Adnan Menderes Üniversitesi Sosyal Bilimler Enstitüsü, Aydın. 